\title{
Too rare for non-timber resource harvest? Meso-scale composition and distribution of arborescent palms in an Amazonian sustainable- use forest
}

Short title: Meso-scale patterns of neotropical arborescent palms

Authors: Darren Norris ${ }^{1,2 *}$, Victor Juan Ulises Rodriguez Chuma ${ }^{1}$, Alexander Roldan Arevalo-Sandi ${ }^{2}$, Omar Stalin Landazuri Paredes ${ }^{1}$, Carlos A. Peres ${ }^{3}$

${ }^{1}$ Programa de Pós-Graduação em Biodiversidade Tropical, Universidade Federal do Amapá, Rod. Juscelino Kubitschek Km 02, Macapá, 68903-419, Brazil

2 Programa de Pós-Graduação em Ecologia, Instituto Nacional de Pesquisas da Amazônia, Avenida André Araújo, 2936, Cx.Postal 478, Aleixo, Manaus, 69060001, AM, Brazil

${ }^{3}$ School Environmental Sciences, University of East Anglia, Norwich, NR47TJ, UK

* Corresponding author, email dnorris75@gmail.com

\section{Highlights}

- The occurrence, density and biomass of adult arborescent palms were measured in a National Forest in the eastern Brazilian Amazon.

- Commercially important arborescent palms were rare.

- Density and biomass were related to hydrographic and topographic variables.

- Subsidised agroforestry practices are required to facilitate the commercialization of palm NTFPs.

Published as:

Norris, D., Chuma, V.J.U.R., Arevalo-Sandi, A.R., Paredes, O.S.L. and Peres, C.A., 2016. Too rare for non-timber resource harvest? Meso-scale composition and distribution of arborescent palms in an Amazonian sustainable-use forest. Forest Ecology and Management, 377, pp.182191. 
Abstract

Arborescent palms can provide an important source of non-timber forest products (NTFPs) within tropical forest REDD+ frameworks. To identify the NTFP potential of arborescent palms, we examined meso-scale patterns of abundance and distribution within a sustainable-use protected area in the eastern Brazilian Amazon. To understand the environmental correlates of observed patterns we evaluated the effects of topography, hydrography and geographic space on the presence, density and biomass of adult arborescent palms. Adult palms were sampled in $30(250 \times 20 \mathrm{~m})$ plots systematically distributed within a $25-\mathrm{km}^{2}$ grid. Topographic and hydrographic variables were derived from a remotely sensed digital elevation model. Spatial correlations in the explanatory and response variables were examined using Mantel tests and GLMs. To test for evidence of dispersal limitation, semi-variograms were used to examine spatial patterns in GLM residuals. Adult arborescent palms were rare occurring in only 12 of the 30 plots. In total, we recorded 118 individuals from six species (Bactris maraja, Euterpe oleracea, Iriartella setigera, Oenocarpus bacaba, Oenocarpus bataua and Oenocarpus minor). This corresponded to a mean live aboveground biomass per plot of $0.85 \mathrm{Mg} \mathrm{ha}^{-1}$ (range: $0-28.1 \mathrm{Mg} \mathrm{ha}^{-1}$ ). Hydrographic and topographic variables suggest that environmental conditions are suitable for $E$. oleracea, an economically important species. The presence, biomass, and density of palms were uncorrelated with geographic distances among plots. The hydrographic model significantly explained variation in palm presence and biomass, whereas density was only explained by the topographic model. Our findings indicate that arborescent palms are currently too rare to be efficiently harvested as NTFPs in the study area. Yet, comparisons with published estimates suggest that there is significant potential for agroforestry to facilitate the commercialization of palm NTFPs for community based extractive activities.

Keywords: Arecaceae; Arecoideae; biomass; canopy palm; meso-scale distribution; palm community 


\section{Introduction}

Commercialisation of non-timber forest products (NTFPs) can contribute to the sustainable management of tropical forests. NTFPs are widely recognised as key components of REDD+ management frameworks and a variety of socio-economic

5 action plans associated with much political will. For example, from January 2012 to December 2013, the Brazilian government invested approximately US\$4.4 million in subsidizing NTFPs from community-based extractive activities (Brazil, 2015). These investments facilitated national commercialization of arborescent palm NTFPs by semisubsistence extractive households, including açaí (Euterpe spp.) fruit, pulp, and palm heart (Brazil, 2015). However, there remains much uncertainty regarding the inclusion of palm NTFPs within forest management plans particularly across poorly studied parts of rural Amazonia.

Brazil has become a world leading example in the development and implementation of management options to reduce deforestation in the Amazon. Yet, the effective management of the 1.6 million $\mathrm{km}^{2}$ of protected areas in the Brazilian Amazon that allow some form of human use remains a global and national challenge (Peres, 2011). Since 2006, the Brazilian government has been granting the private sector the right to manage public forests for the extraction of timber and non-timber products (Law No. 11.284). Although such use can contribute to the erosion of protectionist ideals (de Marques and Peres, 2015), the sustainable use of timber and non-timber products is widely recognised as a key national biodiversity management strategy enabling the integration of socio-economic and biodiversity conservation objectives (Brazil, 2015). With much of the $\sim 1.6$ million $\mathrm{km}^{2}$ sustainable-use protected acreage occupied by sparsely settled human populations [densities $<4$ inhabitants $/ \mathrm{km}^{2}$, (Norris and Michalski, 2013)] the commercialization of palm NTFPs is a rapidly expanding opportunity for community-based agroforestry and forest resource management across Amazonia.

The rural population density across the Brazilian Amazon has generally remained stable or has increased ((IBGE, 2010), see supplemental material in Norris and Michalski (2013)). Additionally, with the stricter controls on deforestation in large farms, the relative contribution of small-scale ( $<100 \mathrm{ha})$ rural farmers for the remaining deforestation in Brazil has also increased in comparison to that of large (>2,500 ha) landowners (Godar et al., 2014). As in much of the tropics, agroforestry is playing an 
increasingly important role as a replacement to slash and burn practices across rural

Amazonia (Lasco et al., 2014; Schneider et al., 2015; Reed et al., 2016). NTFPs represent a key component of these agroforestry management practices (Lasco et al., 2014; Brazil, 2015), generating $\mathrm{R} \$ 935.8$ million, or 5.1\% of the total Brazilian primary forest production in 2011 (Brazil, 2015).

Arborescent palms are an important source of both food and income across the Neotropics (Smith, 2015) and account for over 50\% of the total NTFP commercial revenue in Brazil (Brazil, 2015). Palm NTFPs comprise a key part of priority production chains that can strengthen local production arrangements (Brazil, 2015). Depending on local culture and socio-economics, NTFP extraction of palms can range from simple collection in natural forest to intense cultivation (Richards, 1993; Muñiz-Miret et al., 1996; Weinstein and Moegenburg, 2004; Benjamin Freitas et al., 2015; Smith, 2015; Steele et al., 2015). For example, Mauritia palm (Mauritia flexuosa) and açaí (Euterpe oleracea) are the two most valuable wild fruit species across Amazonia (Smith, 2015). The açaí production chain alone is estimated to generate over US\$ 1 billion in net revenues annually (Brondízio, 2008). Understanding the spatial structure of arborescent palm species richness, density, and biomass is therefore of direct interest to socioeconomic stakeholders, and political decision-makers (Millennium Ecosystem Assessment, 2006).

Palms have myriad growth forms (from small shrubs to tall canopy trees) and are widespread and highly abundant across Amazonia (Terborgh and Andresen, 1998; Balslev et al., 2011; ter Steege et al., 2013). For example, Euterpe is the most abundant tree genus across the entire Amazon, and Euterpe precatoria and E. oleracea are the most and seventh most abundant hyperdominant tree species, respectively (Ter Steege et al., 2013). Arborescent palms also represent a dominant proportion of tree basal area and biomass in central and western Amazon forests (Vormisto et al., 2004; Emilio et al., 2014), but they appear to be less dominant in eastern Amazonia, including areas of the Guianan Shield (Terborgh and Andresen, 1998). Yet even when palms are less dominant and/or less abundant, they can still provide a disproportionate contribution to forest and cultural dynamics due to extended fruiting seasons and high levels of fruit production (Peres, 2000; Link and De Luna, 2004; Cámara-Leret et al., 2014). For example, a study from the eastern Amazon showed that five arborescent palm species (including E. oleracea) were the most important of 27 known palm species for local extractive communities living in and around protected areas (Araújo and Lopes, 2012). 
Previous studies suggest that arborescent palm communities are likely to change as a consequence of extraction (Steele et al., 2015), land-use change (Brum et al., 2008; Eiserhardt et al., 2011) and global warming (Bjorholm et al., 2005; Eiserhardt et al., 2011). Studying determinants of palm community structure and diversity is therefore central to Neotropical forest ecology and management.

Studies have documented broad (biogeographic, e.g. (Göldel et al., 2015)) and local $\left(<1 \mathrm{~km}^{2}\right)$ scale patterns in arborescent palms (Balslev et al., 2011). The principal

75 findings documenting ecological patterns in Neotropical palms come from western and central Amazonia (Balslev et al., 2011; Emilio et al., 2014). Most ecological studies form the eastern Amazon focus on economically important arborescent palms in tidal and floodplain forests (e.g. Benjamin Freitas et al., 2015). There is strong evidence for water-related climatic factors as the primary determinant of broad-scale patterns in the regional to continental scale distribution of palm species (Bjorholm et al., 2005; Bjorholm et al., 2006; Göldel et al., 2015). At more local scales, the composition of arborescent palms is known to change across hydrological and topographic gradients (Kahn and de Castro, 1985; Balslev et al., 2011). Despite this understanding, the low sampling representativeness and lack of studies across vast swathes of the Amazon basin limit our ability to inform the effective management of commercially important palm NTFPs. Here we examine meso-scale patterns of arborescent palms in a $25-\mathrm{km}^{2}$ lowland forest plot of eastern Brazilian Amazonia. Specifically we examine the composition and spatial distribution of palm species within the $25-\mathrm{km}^{2}$ study area, and ask (1) to what extent does topography, hydrography and space influence the occupancy, density and biomass of arborescent palms; (2) whether the species distribution and density of palms are primarily affected by topography or hydrography; and (3) what is the potential of arborescent palms to provide economically viable NTFPs in the study area.

\section{Material and Methods}

\section{Ethics Statement}

Fieldwork was conducted under research permit number IBAMA/SISBIO 47859-1 to DN, issued by the Brazilian Instituto Chico Mendes de Conservação da Biodiversidade (ICMBio). 


\subsection{Study area}

This study was conducted in the Amapá National Forest (Floresta Nacional do Amapá - hereafter, ANF), a sustainable-use protected area of approximately 412,000 ha, centered in the state of Amapá, in north-eastern Brazilian Amazonia $\left(0^{\circ} 55^{\prime} 29^{\prime}\right.$ ' $\mathrm{N}$, $51^{\circ} 35^{\prime} 45^{\prime}$ 'W, Fig. 1). The ANF is located on the pre-Cambrian Guianan shield craton at the base of the Tumucumaque Uplands. The regional climate is hot and humid, with annual rainfall ranging from 2,300 $\mathrm{mm}$ to $2,900 \mathrm{~mm}$ (Oliveira et al., 2010). During the wettest months (February, March and April), rainfall may exceed $500 \mathrm{~mm} / \mathrm{month}$. The dry season (September to November) is characterized by a maximum precipitation below $250 \mathrm{~mm} / \mathrm{month}$ (Oliveira et al., 2010).

The ANF consists of continuous tropical rainforest vegetation, predominantly never-flooded closed canopy "terra firme" forest (ICMBIO, 2014). Canopy trees within the ANF typically reach a height of 25-35 m interspersed with emergents reaching up to $50 \mathrm{~m}$ (ICMBIO, 2014). Based on 14.7 ha of floristic inventories conducted across the ANF (Pereira et al., 2008; ICMBIO, 2014), the 10 most common tree families (accounting for $>60 \%$ of individuals with $\geq 10 \mathrm{~cm} \mathrm{DBH}$ ) were Annonaceae, Apocynaceae, Burseraceae, Chrysobalanaceae, Combretaceae, Fabaceae, Lauraceae, Lecythidaceae, Moraceae, Sapotaceae, which follows the expected pattern for the region (Terborgh and Andresen, 1998; ter Steege et al., 2000; ter Steege et al., 2013). Surveys have recorded 45 commercially valuable timber species within the ANF, with standing commercial timber volume estimates ranging from 21.4 to $52.7 \mathrm{~m}^{3} / \mathrm{ha}$ (ICMBIO, 2014). Considering selective and reduced impact logging activities typically harvest 20 to $30 \mathrm{~m}^{3} / \mathrm{ha}$ in Amazonian forests (Asner et al., 2005; Sist and Ferreira, 2007), these standing volumes are borderline for sustainable commercial exploitation. Such standing volumes combined with the remoteness of the site means there is no short-term expectation (i.e. within the next 5 - 10 years) for the commercial exploitation of timber species within the ANF.

Although the ANF was created in 1989, the management plan was only recently completed and published in 2014 (ICMBIO, 2014). According to Brazilian law (Law No. 9.985/2000) the key objective of sustainable-use areas is the sustainable and multiple uses of native forest resources. One of the objectives of the ANF identified in the management plan is the economic and long-term sustainable use of timber and nontimber forest products (specifically E. oleracea). ANF currently experiences low levels of anthropogenic perturbations (there has been no mechanised logging within the boundaries 
of ANF), largely because only eight families live along the reserve border, there are no

major access roads, and the nearest town is located $46 \mathrm{~km}$ away by river (Norris and Michalski, 2013). The exploitation of NTFPs in the ANF is incipient with an association of 21 local smallholders informally (i.e. lacking commercial production chains) harvesting açaí fruits and producing soap from native tree oilseed extracts (e.g. Carapa guianensis and Copaifera langsdorffii).

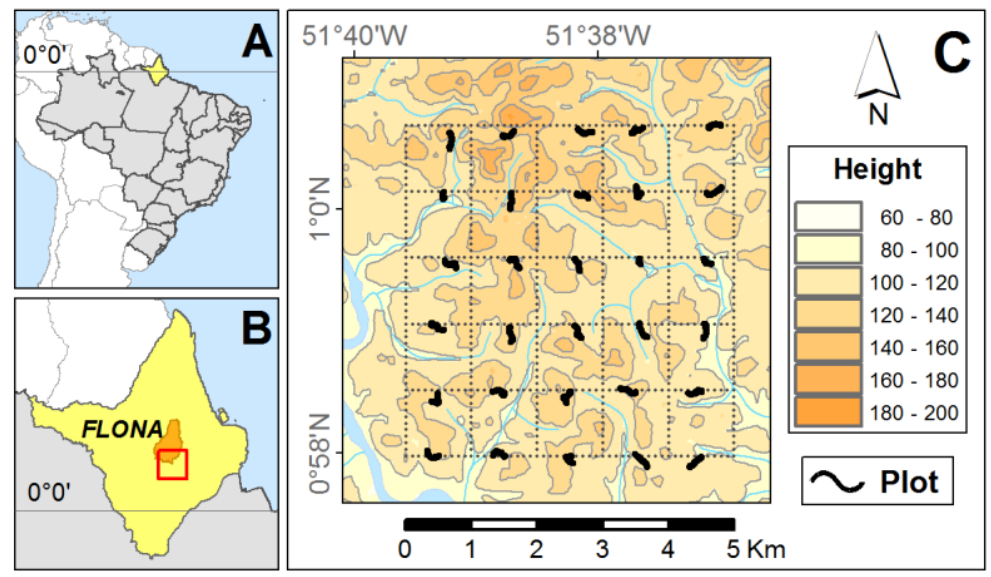

Fig 1. Location of the study region in the Amapá National Forest (ANF), State of Amapá, northeastern Brazilian Amazon. (A) State of Amapá in Brazil. (B) Location of ANF within Amapá. (C) Elevation (20-m) contours across the grid system (dotted lines) and nonlinear plots placed along topographic contours (solid black lines) where palm surveys were conducted.

\subsection{Sampling / Data collection}

Palm surveys were conducted within a $25 \mathrm{~km}^{2}$ area delimited by a series of $5 \mathrm{~km}$ linear transects that form a survey "grid" (Fig. 1). This grid was established as part of the Brazilian Program for Biodiversity Research ["Programa de Pesquisa em Biodiversidade" - hereafter PPBio, (Magnusson et al., 2013)]. Within the grid a total of 30 regularly spaced sample plots were established at 1-km intervals (Fig. 1). This regular arrangement and sample size of 30 plots has been shown to be adequate for capturing variation in meso-scale species diversity responses across lowland Amazonia (Norris et al., 2014).

Palm surveys were conducted during September 2015 in 30 plots of 20 x $250 \mathrm{~m}$ that follow altitudinal contours to minimise the internal variation in both altitude and correlated covariates such as soil type (Magnusson et al., 2005; Magnusson et al., 2013). 
If plots were rectangular this would represent a plot area of 0.5 ha $(250 \mathrm{x} 20 \mathrm{~m})$ and a total survey area of 15 ha. However, due to the nonlinear plots, the total survey area was 18.3 ha (mean plot area $\pm \mathrm{SD}=0.61 \pm 0.09 \mathrm{ha}$ ). The sample grid and plots are located within areas of lowland (50 - 150 m.a.s.l) evergreen terra firme forest or dense ombrophilous rainforest following the Brazilian "universal" vegetation classification system (Veloso et al., 1991). The soil is predominantly low-fertility oxisols, including a mix of red, yellow and red-yellow latosols following the Brazilian soil classification system (Eswaran et al., 2002; ICMBIO, 2014)).

All adult arborescent palms with $\mathrm{DBH} \geq 10 \mathrm{~cm}$ (at $1.3 \mathrm{~m}$ above ground level) were tagged, measured and identified within the 30 plots. The total and stem height of all individuals were estimated visually by previously trained observers. The identity of all palms considered here could easily be determined in situ following field guides (Henderson et al., 1995; de Andrade Miranda, 2001) and identification keys (Kahn, 1990; Rocha and Silva, 2005). Mature fruits of all species were also collected for confirmation by a botanist from the Amapá State Scientific Research and Technology Institute (Instituto de Pesquisas Científicas e Tecnológicas do Estado do Amapá, IEPA) with more than 20 years of experience in palm species identification.

\section{Explanatory variables}

We obtained three topographic and three hydrographic explanatory variables from the SRTM digital elevation model (90-m resolution, version 2 "void filled", downloaded from http://earthexplorer.usgs.gov/). These six explanatory variables were selected, based on findings from previous studies (Terborgh and Andresen, 1998; de Castilho et al., 2006; Poulsen et al., 2006; Costa et al., 2009; Eiserhardt et al., 2011; Göldel et al., 2015; Salm et al., 2015). Topographic variables were selected to represent the form and shape of land surface: slope, aspect and terrain ruggedness. Hydrographic variables represented the spatial distribution of waterbodies and associated features, which are important for plant-soil interactions (e.g. surface inflow, surface moisture content): height above the network drainage (HAND), distance to the nearest stream, and distance to the nearest river.

All topographic and hydrographic variables were calculated using standard GIS procedures (Norris et al., 2014; Michalski et al., 2015). GIS processing was carried out using SAGA (System for Automated Geoscientific Analyses) (http://www.saga- 
gis.org/en/index.html) and Quantum GIS (http://www.qgis.org/en/site/). All variables were weakly correlated (Pearson $r \leq 0.69)$ and as they represent distinct ecological components were retained in subsequent analyses.

All statistical analyses were undertaken within the R language and environment for statistical computing (R Core Team, 2015), using base functions and functions available in the following packages: geoR (Ribeiro Jr and Diggle, 2015), ggplot2 (Wickham, 2009), raster (Hijmans, 2015), sp (Pebesma and Bivand, 2005), tweedie (Dunn, 2014) and vegan (Oksanen et al., 2015).

To estimate the number of species in the $25-\mathrm{km}^{2}$ area we obtained the extrapolated species richness using the second-order jackknife estimator. Given the cross-sectional anatomy and crown architecture of arborescent palms, live tree aboveground dry biomass (AGB) of all individuals was calculated from genus-specific allometric equations, which provide improved AGB estimates compared with standard models developed on the basis of dicot trees [(Goodman et al., 2013), Supplemental Material S1]. A family level model was used for Iriartella setigera and Bactris maraja as genus level models were unavailable [(Goodman et al., 2013); Supplemental Material S1]. We calculated the density and biomass of individuals per species and per plot. Biomass and density values were expressed per hectare.

We tested for spatial auto-correlation of response and explanatory variables with Mantel tests. We calculated association matrices of independent variables as the difference in the value of the variable between plots. We used the Euclidean Distance coefficient to calculate the geographic distance matrix.

We used Generalized Linear Models (GLMs) to explore how topography and hydrography explained the variation in the presence (Binomial error distribution family), and density and biomass (both modelled with Tweedie error distribution family) of arborescent palms. Semi-variograms were used to test for spatial pattern in the GLM residuals.

\section{Results}

3.1 Species composition 
We recorded a total of 118 arborescent palms within the 30 nonlinear plots, providing an overall density of 6.5 ind. ha ${ }^{-1}$. These included six species representing four genera (Table 1), all in the Arecoideae subfamily (Dransfield et al., 2005). We obtained an extrapolated species richness value of 11 . Overall the plots contained an average of 0.5 species. Although some species were relatively common, half of the species recorded were represented by a single individual (Table 1$)$.

E. oleracea was the most abundant species, accounting for $89 \%$ of all palms sampled. The dominance of E. oleracea largely resulted from a single riparian plot (i.e. permanently inundated plot along a perennial river) where $83 \%(\mathrm{n}=98)$ of all individuals were recorded. This riparian plot (“permanent swamp forest”, sensu Kahn and Granville 1992) was identified as an outlier and excluded from subsequent GLM analysis due to the stark differences in environmental characteristics.

Table 1. Density and biomass of arborescent palms in a $25-\mathrm{km}^{2}$ grid of lowland Amazonian terra firme forest.

\begin{tabular}{|c|c|c|c|c|c|}
\hline Tribe / Species ${ }^{\mathrm{a}}$ & $\begin{array}{l}\text { Growth } \\
\text { form }^{\mathrm{b}}\end{array}$ & $\begin{array}{c}\text { Inds. (inds.ha } \\
-1 \text { ) }\end{array}$ & Plots & $\begin{array}{l}\text { Plot Density } \\
\left.\text { (inds.ha }^{-1}\right)^{\mathrm{c}}\end{array}$ & 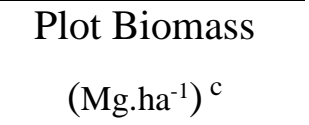 \\
\hline \multicolumn{6}{|l|}{ Cocoseae } \\
\hline Bactris maraja & $\begin{array}{l}\text { Medium- } \\
\text { sized }\end{array}$ & $1(0.05)$ & 1 & 1.6 & 0.01 \\
\hline \multicolumn{6}{|l|}{ Euterpeae } \\
\hline Euterpe oleracea & $\begin{array}{l}\text { Large tall- } \\
\text { stemmed }\end{array}$ & $106(5.80)$ & 3 & $91.1(7.5-255.5)$ & $9.96(0.56-28.07)$ \\
\hline Oenocarpus bacaba & $\begin{array}{l}\text { Large tall- } \\
\text { stemmed }\end{array}$ & $6(0.33)$ & 5 & $1.9(1.4-3.2)$ & $0.65(0.28-1.15)$ \\
\hline Oenocarpus bataua & $\begin{array}{l}\text { Large tall- } \\
\text { stemmed }\end{array}$ & $3(0.16)$ & 3 & $1.6(1.5-1.6)$ & $0.58(0.42-0.80)$ \\
\hline Oenocarpus minor & Small & $1(0.05)$ & 1 & 1.5 & 1.11 \\
\hline \multicolumn{6}{|l|}{ Iriarteeae } \\
\hline Iriartella setigera & Small & $1(0.05)$ & 1 & 1.8 & 0.12 \\
\hline
\end{tabular}




\subsection{Occupancy, density and biomass}

Adult arborescent palms were recorded in only 12 of the 30 plots and only two plots contained more than one species ( 2 species in both cases, Fig. 2). From the total of 118 individual palms we calculated an overall live aboveground biomass of $15.63 \mathrm{Mg}$, resulting in a mean biomass of $0.85 \mathrm{Mg} \mathrm{ha}^{-1}$ for the 18.3 ha cumulative plot area. Summing values from all species the median plot biomass was $0.11 \mathrm{Mg} \mathrm{ha}^{-1}(95 \%$ quantiles for 30 plots: $0-1.27 \mathrm{Mg} \mathrm{ha}^{-1}$ ).

None of the three responses were correlated with geographic distances among plots (Mantel tests: $\mathrm{P}=0.88, \mathrm{P}=0.38$ and $\mathrm{P}=0.35$, for occupancy, biomass and density, respectively), which was also confirmed by visual inspection of the mapped values (Fig. 2). There was no significant correlation between the geographic distances among plots and any of the six explanatory variables (Mantel test: $\mathrm{P} \geq 0.33$ ).
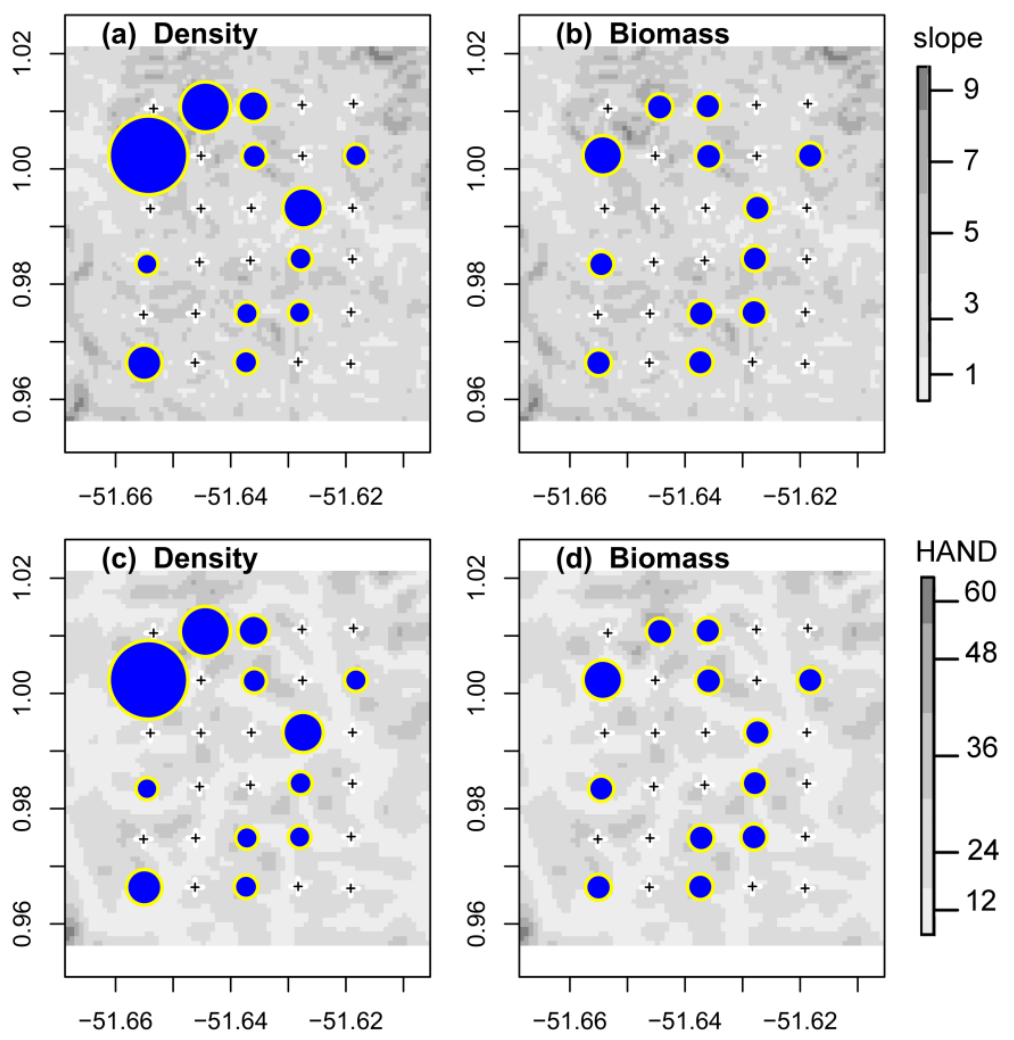

255 Fig 2: Spatial patterns in arborescent palm density and biomass. Location of the 30 plots are shown with size of blue spheres proportional to palm density (left panels) and biomass values (right panels). Crosses denote locations of plots with no arborescent palms. Mapped values of the most important topographic and hydrographic variables 
shown as grey shaded background for slope (panels (a) and (b)) and height above the network drainage (panels (c) and (d)).

Palm density varied more than palm biomass between plots (Fig. 2). Plot-wise differences in the biomass of arborescent palms were only weakly explained by topography and hydrography (Table 2). Presence and biomass were best explained by hydrographic variables (Table 2), with both responses increasing significantly with HAND elevation above the landscape drainage (Table 2, Fig. 3). Variation in density was most strongly explained by topography, with significant negative and positive relationships with slope and terrain ruggedness respectively (Table 2). None of the unexplained variation (model residuals) was related to the geographic distance among plots (Supplemental Material S2).

(a)

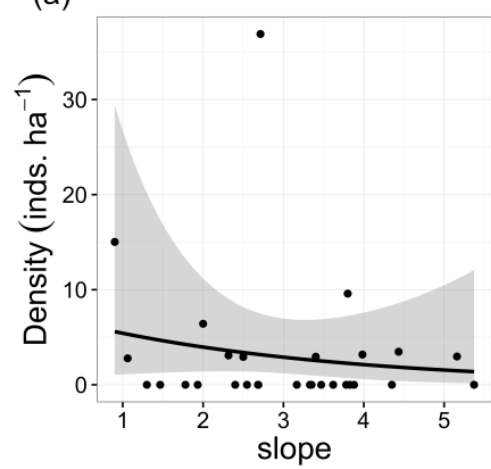

(c)

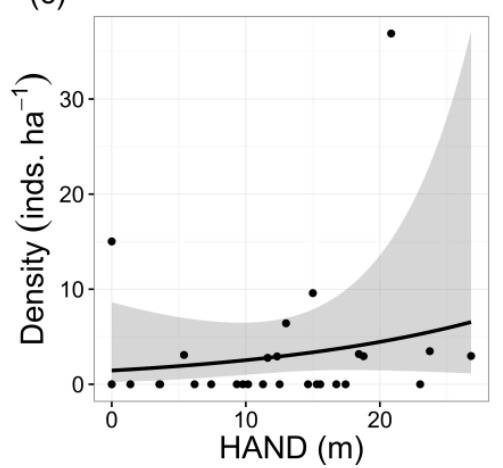

(b)

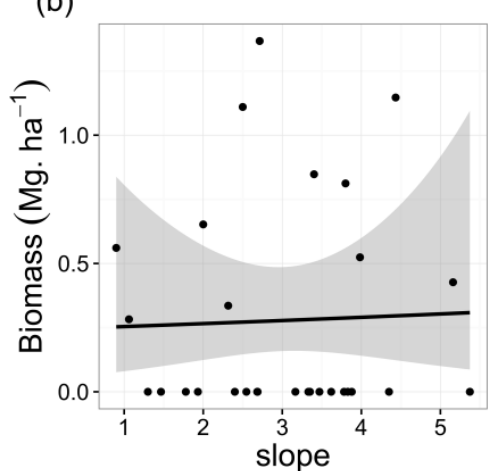

(d)

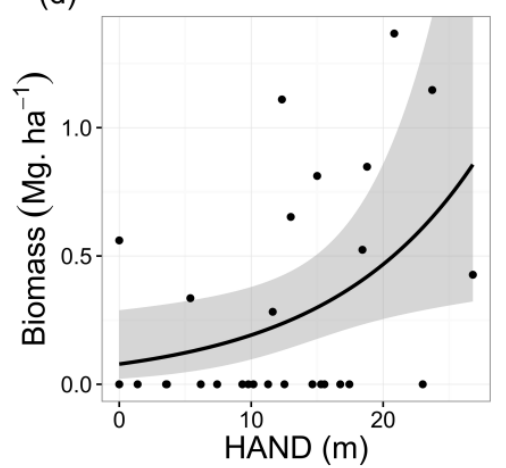

Fig 3: Relationship between arborescent palm density and biomass and slope and height above the network drainage (HAND). Solid dots show values from 29 lowland terra firme plots in Amapá National Forest, Brazil. Solid line shows trend with grey shading showing 95\% confidence intervals from GLMs (Tweedie error distribution). 
Table 2. Variation in arborescent palm distribution in relation to topography and hydrography. Results from GLMs used to explain the variation in occupancy, density and biomass of arborescent palms recoded from 29 lowland terra firme forest plots in Amapá National Forest, Brazil.

\begin{tabular}{|c|c|c|c|c|c|c|}
\hline \multirow{2}{*}{ Model } & \multicolumn{2}{|l|}{ Presence } & \multicolumn{2}{|c|}{ Density } & \multicolumn{2}{|c|}{ Biomass } \\
\hline & ${ }^{\mathrm{a}} \mathrm{Est}(\mathrm{SE})$ & $\operatorname{Rank}^{\mathrm{c}}$ & ${ }^{\mathrm{a}}$ Est (SE) & $\operatorname{Rank}^{\mathrm{c}}$ & ${ }^{\mathrm{a}}$ Est (SE) & $\operatorname{Rank}^{\mathrm{c}}$ \\
\hline \multicolumn{7}{|c|}{ Model 1 - Topography } \\
\hline Intercept & $-0.50(0.39)$ & & $0.87(0.35)$ & & $-1.31(0.29)$ & \\
\hline Slope & $0.12(0.55)$ & 3 & $-0.90(0.49) *$ & 1 & $-0.01(0.41)$ & 3 \\
\hline Aspect & $0.18(0.39)$ & 2 & $0.17(0.32)$ & 3 & $0.23(0.28)$ & 1 \\
\hline TRI & $-0.32(0.57)$ & 1 & $0.74(0.41)^{*}$ & 2 & $-0.11(0.38)$ & 2 \\
\hline AIC & 45.9 & & 111.3 & & 54.3 & \\
\hline${ }^{\mathrm{b}}$ Dev. expl & 1.5 & & $17.3 *$ & & 2.6 & \\
\hline \multicolumn{7}{|c|}{ Model 2 - Hydrography } \\
\hline Intercept & $-0.56(0.41)$ & & $0.94(0.43)$ & & $-1.51(0.31)$ & \\
\hline HAND & $0.83(0.55)^{*}$ & 1 & $0.31(0.49)$ & 2 & $0.66(0.33)^{*}$ & $* 1$ \\
\hline Dist. river & $0.20(0.41)$ & 2 & $0.43(0.43)$ & 1 & $0.23(0.28)$ & 2 \\
\hline Dist. creek & $-0.08(0.52)$ & 3 & $0.18(0.50)$ & 3 & $-0.09(0.35)$ & 3 \\
\hline AIC & 42.5 & & 113.0 & & 50.1 & \\
\hline${ }^{\mathrm{b}}$ Dev. expl & $10.3 *$ & & 11.2 & & $20.3 *$ & \\
\hline
\end{tabular}

Significant models in bold, significance codes: '*’ 0.01 , ‘**’ 0.05

${ }^{a}$ Standardized regression coefficient and associated standard error (SE).

${ }^{\mathrm{b}}$ Model deviance explained (\%)

285 c Ranked variable importance based on z ("Presence") or t ("Density" and "Biomass") test probability values.

\subsection{Species distribution and density}

Only three species occurred in more than one plot (O. bacaba, O. bataua and $E$. oleracea; Fig. 3). Oenocarpus bacaba was the most widely distributed species, but was only recorded in $17 \%$ of the plots (Table 1, Fig. 4). Although only present in five plots this species was recorded across the entire topographic and hydrographic gradient 
examined (Fig. 4). With a density of $255.5 \mathrm{stems} \mathrm{ha}^{-1}$, E. oleracea was most abundant in the flooded plot (Table 1), but this species was also absent from three other unflooded plots with the same HAND value (Fig. 4). E. oleracea was also recorded at plots with higher HAND values (Fig. 4). Oenocarpus bataua was found in plots with greater HAND and slope values (Fig. 4).

(a)

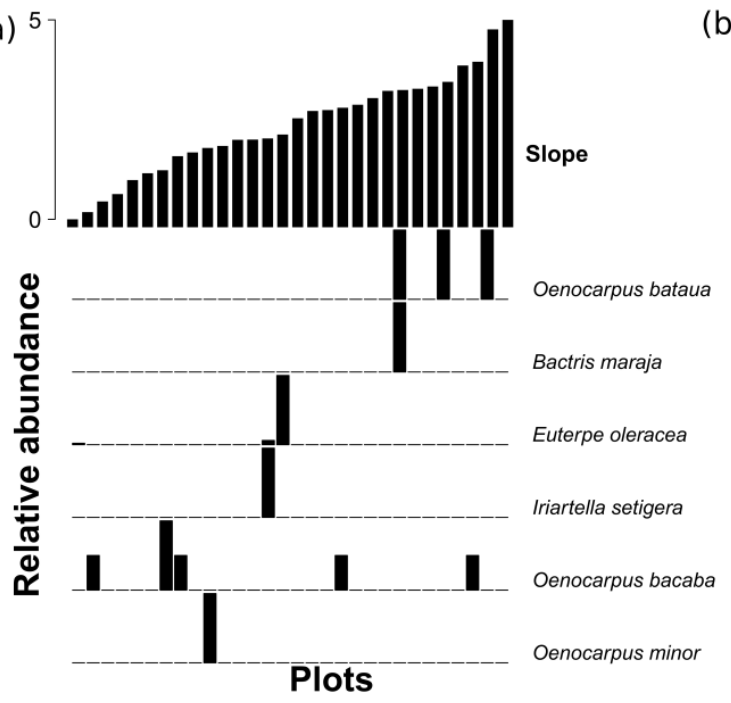

(b)

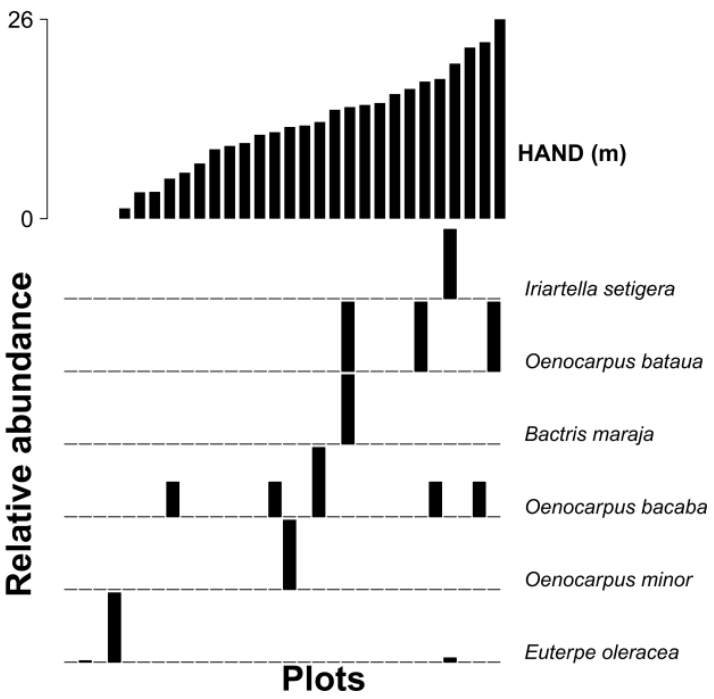

300 Fig. 4. Direct ordination of arborescent palm species abundance data in 30 lowland Amazonian terra firme forest plots, showing species abundances in relation to gradients in slope (a) and height above the network drainage (b). Plots (x-axes) are ordered left to right from lowest to highest slope and HAND values. Bars indicate relative abundance in a given plot within species but are not comparable between species because the number of individuals varied among species (Table 1). Values of the y-axis in the top bar plots represent the range of gradient values.

\section{Discussion}

\subsection{Species composition}

Our study region has a relatively high species richness of palms (Bjorholm et al., 2006; Göldel et al., 2015), with the Arecoideae showing a strong mid-domain effect whereby 
species richness peaks around the equator (Bjorholm et al., 2006). We recorded six arborescent palm species from $18 \mathrm{ha}\left(0.18 \mathrm{~km}^{2}\right)$ of forest. Findings from previous studies show that we could expect as many as 25 or more caulescent ("stemmed") palms within a 101 x $101 \mathrm{~km}\left(10,201 \mathrm{~km}^{2}\right)$ area (supplementary figure S1a in Göldel et al. 2015). Although stemmed palms is the most common growth form in the Arecaceae (Göldel et al., 2015), most stemmed species are classified as "understory" palm, 320 whereas arborescent canopy and subcanopy palms are typically less species-rich in lowland Amazonia (Kahn and de Castro, 1985; Costa et al., 2009). For example, in central Amazonia, only five of a total of 32 palm species recorded from 1.2 ha were arborescent (Kahn and de Castro, 1985). A study from this same region recorded 11 species of "canopy" palms (typically $>8 \mathrm{~m}$ ) from a total of 38 species in 7.2 ha (Costa et al., 2009). In contrast, studies in the Guianan Shield (NW Guyana) reported very low numbers of palms (e.g. 4.6 trees/hectare) (Davis and Richards, 1934; Kahn and Granville, 1992). Our estimated and observed species richness values are therefore within the expected range considering the location and overall size of our study area. We obtained an estimate of 11 arborescent palm species from our survey of thirty 250 x $20 \mathrm{~m}$ plots within the $25-\mathrm{km}^{2}$ grid, suggesting that several species remain undetected. Previous studies report Attalea sp. and Astrocaryum sp. as commonly found arborescent palms from lowland forests in central and western Amazonia. Species from these genera provide commercially marketable NTFPs (Smith, 2015), and have been reported from studies across the Guianan Shield (Smith, 2015). Therefore, it seems likely that Attalea sp. and Astrocaryum sp. do occur within the ANF. However, our survey suggests that these species are likely to be rare across the area and do not represent a source of commercially viable NTFPs.

\subsection{Occupancy, biomass and density}

340 Our occupancy, biomass and density values are generally lower than those reported from other regions in central and western Amazonia (Kahn and de Castro, 1985; Terborgh and Andresen, 1998; ter Steege et al., 2000; de Castilho et al., 2006; Costa et al., 2009; Goodman et al., 2013). Previous studies provide live tree aboveground dry biomass estimates of $434 \mathrm{Mg} \mathrm{ha}^{-1}$ (95\% CI: 293.9-763.4 $\mathrm{Mg} \mathrm{ha}^{-1}$ ) from 45 permanent

345 tropical forest plots in the Guianan Shield (Feldpausch et al., 2012). Based on our plotwise mean estimate, adult arborescent palms represented $<0.2 \%\left(0.85 / 434 \mathrm{Mg} \mathrm{ha}^{-1}\right)$ 
of the total aboveground biomass. However, considering the maximum biomass value obtained from the plot dominated by E. oleracea $\left(28.07 \mathrm{Mg} \mathrm{ha}^{-1}\right)$ then arborescent palms represented up to $10 \%$ of the overall biomass $\left(28.07 / 293.9 \mathrm{Mg} \mathrm{ha}^{-1}\right)$. clustered and unpredictable (Kahn and Granville, 1992; Eiserhardt et al., 2011; Göldel et al., 2015). The density of canopy palms in Amazonian terra firme forests may range from low (< 40 individuals per ha) to more than 200 individuals per ha in oligarchic or monotypic forests (Kahn and Granville, 1992; Peres, 1994; Benjamin Freitas et al., 2015). The weak explanatory power of our GLMs for occupancy, biomass and density of adult arborescent palms is therefore to be expected. There are several alternate nonmutually exclusive explanations for the observed patterns. Firstly, palms were rare in our study plots and modelling rare species is notoriously challenging. Although our findings generally agree with those of previous studies, much unexplained variation in the GLMs remain. Secondly, we did not consider edaphic factors, which have been shown to be important drivers of arborescent palm species composition (Costa et al., 2009) and biomass (de Castilho et al., 2006). However, topography and hydrography are strongly related to meso-scale soil characteristics in lowland Amazonia. Indeed elevation is so strongly correlated with soil characteristics that their effects cannot be easily separated (de Castilho et al., 2006; Poulsen et al., 2006; Costa et al., 2009), leading to the conclusion that topography is an adequate proxy for meso-scale soil properties (de Castilho et al., 2006; Costa et al., 2009). As such we believe soil properties are unlikely to provide additional insights beyond those provided by our topographic and hydrological covariates.

Dispersal limitation has been proposed to explain unpredictable patterns in arborescent palm density and diversity (Svenning, 2001; Bjorholm et al., 2005). Yet, we found no obvious spatial structure in meso-scale palm distribution. No correlation was found between any of the responses and the geographic distance among plots. When combined with the fact that, when controlling for topographic and hydrological effects, 375 there was no association with spatial distance, we conclude that meso-scale dispersal limitation does not operate in our study area. Indeed the relatively pristine forest status of the Amapá National Forest ensures the presence of a full complement of vertebrate dispersers including tapir, large primates and scatter-hoarding rodents [(Michalski et al., 2015), D. Norris, pers. obs.]. 

patterns of palm species distribution at local and landscape scales (Fragoso, 1997; Sezen et al., 2009). For example, dispersal effects are evident at local scales in the distance decay of floristic similarity and are also suggested to be responsible for large fractions of unexplained variation at this scale (Normand et al., 2006). Considering the importance of such biotic and abiotic interactions, the unexplained variation in palm occupancy, density, and biomass is therefore unsurprising and supports findings from previous studies (Eiserhardt et al., 2011).

\subsection{Species distribution and density}

390 The three most common arborescent palms at ANF are early successional species that have been recorded across a range of environmental gradients (Peres, 1994; Henderson et al., 1995; Svenning, 1999; Pacheco, 2001; Brum et al., 2008; Ter Steege et al., 2013). Both species of Oenocarpus (O. bacaba and $O$. bataua) are widely distributed throughout Neotropical evergreen forests on both sides of the Andes (Henderson et al., 1995; Smith, 2015). We recorded both species in upland plots above $5 \mathrm{~m}$ from the drainage network, with most individuals recorded at higher elevation plots (HAND > 10 m). Previous studies show that inundation inhibits germination in O. bacaba (Pacheco, 2001). This finding may explain the increased abundance of this species on plateau and slope ridges compared to lowland areas (i.e. $<5 \mathrm{~m}$ above stream level) (Pacheco, 2001). In contrast $O$. bataua has been recorded from terra firme forests in the western Amazon (Vormisto et al., 2004) and in floodplain areas in central Amazon (Kahn and de Castro, 1985).

Previous studies show that $O$. bataua can be 20-fold more abundant than $O$. bacaba across both wet and dry forests in western South America (Amazon, Chocó and montane forest habitats) (Cámara-Leret et al., 2014). In contrast, O. bacaba dominates well drained terra firme forests in the central Amazon but was absent from floodplain areas where O. bataua dominates (Kahn and de Castro, 1985). In the ANF both species were rare compared with the results from these previous studies and were never recorded in the same plot. Although there are methodological differences (such as the

410 minimum DBH cut-off) previous studies report density values that are substantially (310 fold) greater than those at ANF. For example the mean stem density of large ( $>10 \mathrm{~cm}$ 
DBH) O. bacaba was 5 ind. ha ${ }^{-1}$ within 21 central Amazon terra firme forest plots of 1 ha each (Brum et al., 2008).

Euterpe oleracea is known for its strong association with floodplain and tidal várzea forest areas (Muñiz-Miret et al., 1996; Weinstein and Moegenburg, 2004; Fortini and Carter, 2014), which are often exploited for the commercial management of the species (Weinstein and Moegenburg, 2004; Smith, 2015). We recorded E. oleracea both at and above the drainage network $(0-20 \mathrm{~m})$. The fact that this species occurs above the drainage network is consistent with other studies showing this species can occur in a variety of topographic and hydrographic conditions (Vedel-Sorensen et al., 2013). But as found for the two Oenocarpus species the density of E. oleracea in the ANF was much lower than those reported from central Amazon areas (Kahn and de Castro, 1985; Costa et al., 2009).

\subsection{NTFP potential of arborescent palms}

Economically viable densities of adult arborescent palms are likely to be orders of magnitude above the values we recorded at ANF. For example, in commercially managed floodplain areas, E. oleracea density ranges between 200 and 1000 stems ha $^{-1}$ (Benjamin Freitas et al., 2015). Açaí production from semi-natural oligarchic palm stands arguably accrues the highest socio-economic value at local to national scales from any nontimber neotropical forest resource (Muñiz-Miret et al., 1996; Heckenberger et al., 2007; Cámara-Leret et al., 2014; Benjamin Freitas et al., 2015). In contrast the commercialization of Oenocarpus remains much less important locally, and we could not find any published reports from our region of NTFP trade of these species. Due to the overall rarity of arborescent palms at ANF, and the apparent lack of a local market for Oenocarpus sp., we focus on E. oleracea as the most viable palm NTFP option that could be harvested for either subsistence or cash.

Management of insufficiently dense resource populations may be required to boost stocks of commercially valuable NTFPs. Although recent studies highlight

440 degradation of forest diversity within monodominant açaí stands (Weinstein and Moegenburg, 2004; Benjamin Freitas et al., 2015), the recommended açaí management practice for smallholders is agroforestry, in which areas with 200-400 açaí stems per ha can still retain 200 native forest trees $\mathrm{ha}^{-1}$ (Queiroz and Mochiutti, 2012). Adoption of agroforestry management practices reduces biodiversity impacts and increases açaí fruit 
445 production. For example, these agroforestry mosaics can extend açaí fruiting periods from 3 to 7 months (Queiroz and Mochiutti, 2012), thereby significantly increasing NTFP productivity within smallholdings.

A comparison of smallholder açaí and micro scale timber producing firms from around the Amazon estuary found that average start-up costs for clearing and planting 1 ha of açaí was US\$948 (Fortini and Carter, 2014), compared to an annual revenue of US\$1040 assuming the average açaí stand density. These authors also found that the financial break-even point based on açaí sales was relatively long at 8 years, largely because of the 3-5 years between planting and full production (Hiraoka, 1995; Fortini and Carter, 2014). If smallholder açaí production is deemed as an acceptable choice in balancing conservation and local livelihoods in and around sustainable-use protected areas, then our findings suggest that subsidies and/or financial assistance will be needed to fund the start-up and management costs during pre-production years.

The ANF management plan establishes a 26,208 ha zone for community-based extractive activities, including nontimber resources. Assuming that lowland areas accessible within $2000 \mathrm{~m}$ of the main river and with HAND values below $1 \mathrm{~m}$ are likely suitable for commercial açaí agroforestry plantations, the results of our HAND model suggest that approximately 2,845 ha ( $11 \%$ of the 26,208 ha zone) is available for commercial açaí planting. Assuming an average yearly revenue of US $\$ 1040$ per hectare (Fortini and Carter, 2014), this provides an estimate of US\$2,958,800 per year from commercial açaí production for the local residents in and around the ANF.

There are a total of 8 families who live along the ANF border and a further 23 within $20 \mathrm{~km}$ (Norris and Michalski, 2013). It is estimated that 12.5 ha of permanent açaí cultivation would be required to provide the equivalent net present value of commercially valuable timber purchased by a sawmill (Fortini and Carter, 2014). Therefore, allocating 12.5 ha for commercial production per family (smallholders typically manage between 10 and 20 ha in the region) would require a total area of 388 ha, thereby generating a mean gross annual revenue of US\$13,000 per family. Although there are large uncertainties in these revenue estimates arising from a variety of economic, management and environmental challenges, a rural worker in Brazil earns on average US\$468 per month (IBGE, 2013) and in our study region, the principal earner from the families living around the ANF earns on average US\$ 500 per month [(Norris and Michalski, 2013), 2012 exchange rate of US\$1.00 to R \$1.70]. Revenue 
from the effective management and commercialisation of palm NTFPs can therefore represent significant opportunities that remain under-exploited.

\subsection{Conclusion}

Based on our results, we conclude that hydrography and topography have direct but distinct effects of the occupancy, density and biomass of adult arborescent palms at ANF. Based on the findings from our ecological models, and the economic potential of E. oleracea NTFPs, we consider that with appropriate management the proportional area designated for extractive activities within sustainable-use Amazonian forest reserves appears to be adequate to generate significant socio-economic benefits for the rural population. Our findings emphasize that management of arborescent palms within an extensively managed agroforestry context will be necessary to realise the full socioeconomic and conservation potential of sustainable-use protected areas. This is particularly important in the National Forests of Brazilian Amazonia, where marketcompetitive NTFP extractive activities can stave off the economic alternative of allocating much larger areas to corporate logging concessions, which are far more powerful agents of forest degradation.

\section{Acknowledgements}

The Instituto Chico Mendes de Conservação da Biodiversidade (ICMBio) and the Federal University of Amapá (UNIFAP) provided logistical support. We thank IBAMA for authorization to conduct research in ANF (IBAMA/SISBIO permit 47859-1). We thank the Brazilian Long-term Biodiversity Monitoring Program (PPBIO) for providing the grid system used during field activities. We thank Érico Emed Kauano and Sueli Gomes Pontes dos Santos for assistance during the field campaigns. We thank Yuri Breno da Silva and Edielza Aline dos Santos Ribeiro for their help during data collection. We are deeply indebted to Cremilson and Cledinaldo Alves Marques for their dedication, commitment and assistance during fieldwork. We also thank Fernanda Michalski and Nigel Pitman who provided comments on previous versions of the manuscript. 


\section{Financial statement}

510 The authors thank the Brazilian National Counsel of Technological and Scientific Development (“Conselho Nacional de Desenvolvimento Científico e Tecnológico” $\mathrm{CNPq}$ ) for the financial support provided through the "MCTI/CNPQ/Universal 14/2014" grant number 446926/2014-0. DN thanks the Brazilian Coordination for the Improvement of Higher Education Personnel ("Coordenação de Aperfeiçoamento de

515 Pessoal de Nível Superior" - CAPES) for the scholarship and financial support granted (grant number PNPD20130074). The funders had no role in study design, data collection and analysis, decision to publish, or preparation of the manuscript.

\section{References}

520 Araújo, F.R., Lopes, M.A., 2012. Diversity of use and local knowledge of palms (Arecaceae) in eastern Amazonia. Biodiversity and Conservation 21, 487-501.

Asner, G.P., Knapp, D.E., Broadbent, E.N., Oliveira, P.J., Keller, M., Silva, J.N., 2005. Selective logging in the Brazilian Amazon. Science 310, 480-482.

Balslev, H., Kahn, F., Millan, B., Svenning, J.-C., Kristiansen, T., Borchsenius, F., Pedersen, D.,

525 Eiserhardt, W.L., 2011. Species diversity and growth forms in tropical American palm communities. The Botanical Review 77, 381-425. http://dx.doi.org/10.1007/s12229-011-9084$\underline{x}$.

Benjamin Freitas, M.A., Guimaraes Vieira, I.C., Kerti Mangabeira Albernaz, A.L., Lima Magalhaes, J.L., Lees, A.C., 2015. Floristic impoverishment of Amazonian floodplain forests

530 managed for acai fruit production. Forest Ecology and Management 351, 20-27. http://dx.doi.org/10.1016/j.foreco.2015.05.008.

Bjorholm, S., Svenning, J.C., Baker, W.J., Skov, F., Balslev, H., 2006. Historical legacies in the geographical diversity patterns of New World palm (Arecaceae) subfamilies. Botanical Journal of the Linnean Society 151, 113-125. http://dx.doi.org/10.1111/i.1095-8339.2006.00527.x.

535 Bjorholm, S., Svenning, J.C., Skov, F., Balslev, H., 2005. Environmental and spatial controls of palm (Arecaceae) species richness across the Americas. Global Ecology and Biogeography 14, 423-429. http://dx.doi.org/10.1111/j.1466-822x.2005.00167.x.

Brazil, M.o.t.E., 2015. Fifth National Report to the Convention on Biological Diversity. In: SBF, S.o.B.a.F.-. (Ed.). Brazil: Ministry of the Environment, Brasília, Brazil.

540 Brum, H.D., Nascimento, H.E.M., Laurance, W.F., Andrade, A.C.S., Laurance, S.G., Luiza, R.C.C., 2008. Rainforest fragmentation and the demography of the economically important palm 
Oenocarpus bacaba in central Amazonia. Plant Ecology 199, 209-215.

http://dx.doi.org/10.1007/s11258-008-9425-y.

Cámara-Leret, R., Paniagua-Zambrana, N., Balslev, H., Barfod, A., Copete, J.C., Macía, M.J.,

2014. Ecological community traits and traditional knowledge shape palm ecosystem services in northwestern South America. Forest Ecology and Management 334, 28-42.

http://dx.doi.org/10.1016/j.foreco.2014.08.019.

Costa, F.R., Guillaumet, J.L., Lima, A.P., Pereira, O.S., 2009. Gradients within gradients: The mesoscale distribution patterns of palms in a central Amazonian forest. Journal of Vegetation Science 20, 69-78. http://dx.doi.org/10.1111/j.1654-1103.2009.05314.x.

Davis, T.A.W., Richards, P.W., 1934. The vegetation of Moraballi Creek, British Guiana: an ecological study of a limited area of tropical rain forest. Part II. The Journal of Ecology, 106155.

de Andrade Miranda, I.P., 2001. Frutos de palmeiras da Amazônia. Presidência da República,

555 Ministério da Ciência e Tecnologia, Instituto Nacional de Pesquisas da Amazônia.

de Castilho, C.V., Magnusson, W.E., de Araújo, R.N.O., Luizao, R.C., Luizao, F.J., Lima, A.P., Higuchi, N., 2006. Variation in aboveground tree live biomass in a central Amazonian Forest: Effects of soil and topography. Forest ecology and management 234, 85-96.

http://dx.doi.org/10.1016/j.foreco.2006.06.024.

560 de Marques, A.A.B., Peres, C.A., 2015. Pervasive legal threats to protected areas in Brazil. Oryx 49, 25-29. http://dx.doi.org/10.1017/\$0030605314000726.

Dransfield, J., Uhl, N.W., Asmussen, C.B., Baker, W.J., Harley, M.M., Lewis, C.E., 2005. A new phylogenetic classification of the palm family, Arecaceae. Kew Bulletin, 559-569.

Dunn, P.K., 2014. tweedie: Tweedie exponential family models. https://cran.r-

565 project.org/web/packages/tweedie.

Eiserhardt, W.L., Svenning, J.-C., Kissling, W.D., Balslev, H., 2011. Geographical ecology of the palms (Arecaceae): determinants of diversity and distributions across spatial scales. Annals of Botany 108, 1391-1416. http://dx.doi.org/10.1093/aob/mcr146.

Emilio, T., Quesada, C.A., Costa, F.R., Magnusson, W.E., Schietti, J., Feldpausch, T.R., Brienen,

570 R.J., Baker, T.R., Chave, J., Álvarez, E., 2014. Soil physical conditions limit palm and tree basal area in Amazonian forests. Plant Ecology \& Diversity 7, 215-229.

http://dx.doi.org/10.1080/17550874.2013.772257.

Eswaran, H., Ahrens, R., Rice, T.J., Stewart, B.A., 2002. Soil classification: a global desk reference. CRC Press.

575 Feldpausch, T.R., Lloyd, J., Lewis, S.L., Brienen, R.J.W., Gloor, M., Monteagudo Mendoza, A., Lopez-Gonzalez, G., Banin, L., Abu Salim, K., Affum-Baffoe, K., Alexiades, M., Almeida, S., 
Amaral, I., Andrade, A., Aragão, L.E.O.C., Araujo Murakami, A., Arets, E.J.M.M., Arroyo, L., Aymard C, G.A., Baker, T.R., Bánki, O.S., Berry, N.J., Cardozo, N., Chave, J., Comiskey, J.A., Alvarez, E., de Oliveira, A., Di Fiore, A., Djagbletey, G., Domingues, T.F., Erwin, T.L., Fearnside, P.M., França, M.B., Freitas, M.A., Higuchi, N., C, E.H., lida, Y., Jiménez, E., Kassim, A.R., Killeen, T.J., Laurance, W.F., Lovett, J.C., Malhi, Y., Marimon, B.S., Marimon-Junior, B.H., Lenza, E., Marshall, A.R., Mendoza, C., Metcalfe, D.J., Mitchard, E.T.A., Neill, D.A., Nelson, B.W., Nilus, R., Nogueira, E.M., Parada, A., Peh, K.S.H., Pena Cruz, A., Peñuela, M.C., Pitman, N.C.A., Prieto, A., Quesada, C.A., Ramírez, F., Ramírez-Angulo, H., Reitsma, J.M., Rudas, A., Saiz, G., Salomão, R.P., Schwarz, M., Silva, N., Silva-Espejo, J.E., Silveira, M., Sonké, B., Stropp, J., Taedoumg, H.E., Tan, S., ter Steege, H., Terborgh, J., Torello-Raventos, M., van der Heijden, G.M.F., Vásquez, R., Vilanova, E., Vos, V.A., White, L., Willcock, S., Woell, H., Phillips, O.L., 2012. Tree height integrated into pantropical forest biomass estimates. Biogeosciences 9, 3381-3403. http://dx.doi.org/10.5194/bg-9-3381-2012.

590 Fortini, L.B., Carter, D.R., 2014. The economic viability of smallholder timber production under expanding açaí palm production in the Amazon Estuary. Journal of Forest Economics 20, 223235. http://dx.doi.org/10.1016/i.jfe.2014.06.001.

Fragoso, J.M.V., 1997. Tapir-Generated Seed Shadows: Scale-Dependent Patchiness in the Amazon Rain Forest. Journal of Ecology 85, 519-529. http://dx.doi.org/10.2307/2960574.

595 Godar, J., Gardner, T.A., Tizado, E.J., Pacheco, P., 2014. Actor-specific contributions to the deforestation slowdown in the Brazilian Amazon. Proceedings of the National Academy of Sciences 111, 15591-15596. 10.1073/pnas.1322825111.

Göldel, B., Kissling, W.D., Svenning, J.-C., 2015. Geographical variation and environmental correlates of functional trait distributions in palms (Arecaceae) across the New World. Botanical Journal of the Linnean Society 179, 602-617. http://dx.doi.org/10.1111/boj.12349. Goodman, R.C., Phillips, O.L., del Castillo Torres, D., Freitas, L., Cortese, S.T., Monteagudo, A., Baker, T.R., 2013. Amazon palm biomass and allometry. Forest Ecology and Management 310, 994-1004. http://dx.doi.org/10.1016/j.foreco.2013.09.045.

Heckenberger, M.J., Russell, J.C., Toney, J.R., Schmidt, M.J., 2007. The legacy of cultural landscapes in the Brazilian Amazon: implications for biodiversity. Philosophical Transactions of the Royal Society B: Biological Sciences 362, 197-208.

http://dx.doi.org/10.1098/rstb.2006.1979.

Henderson, A., Galeano-Garces, G., Bernal, R., 1995. Field guide to the palms of the Americas. Princeton University Press.

610 Hijmans, R.J., 2015. raster: Geographic Data Analysis and Modeling. https://CRAN.Rproject.org/package=raster. 
Hiraoka, M., 1995. Land use changes in the Amazon estuary. Global Environmental Change 5, 323-336. http://dx.doi.org/10.1016/0959-3780(95)00066-W.

IBGE. 2010. Censo emográfico 2010.

http://www.ibge.gov.br/home/estatistica/populacao/censo2010/default.shtm.

IBGE. 2013. Pesquisa Nacional por Amostra de Domicílios de 2011 a 2012.

http://www.ibge.gov.br/home/estatistica/populacao/trabalhoerendimento/pnad2012/default .shtm.

ICMBIO, 2014. Plano de Manejo da Floresta Nacional do Amapá, Macapa.

Kahn, F., 1990. Identification of Amazonian palm genera from vegetative characters. Principes 34, 199-207.

Kahn, F., de Castro, A., 1985. The palm community in a forest of central Amazonia, Brazil. Biotropica, 210-216.

Kahn, F., Granville, J.-J.d., 1992. Palms in forest ecosystems of Amazonia. Springer-Verlag, London.

Lasco, R.D., Delfino, R.J.P., Catacutan, D.C., Simelton, E.S., Wilson, D.M., 2014. Climate risk adaptation by smallholder farmers: the roles of trees and agroforestry. Current Opinion in Environmental Sustainability 6, 83-88. http://dx.doi.org/10.1016/j.cosust.2013.11.013. Link, A., De Luna, A.G., 2004. The importance of Oenocarpus bataua (Arecaceae) in the diet of 630 spider monkeys at Tinigua National Park, Colombia. Folia Primatologica 75, 391-391. Magnusson, W., Braga-Neto, R., Pezzini, F., Baccaro, F., Bergallo, H., Penha, J., Rodrigues, D., Verdade, L.M., Lima, A., Albernaz, A.L., Hero, J.-M., Lawson, B., Castilho, C., Drucker, D., Franklin, E., Mendonça, F., Costa, F., Galdino, G., Castley, G., Zuanon, J., do Vale, J., Campos dos Santos, J.L., Luizão, R., Cintra, R., Barbosa, R.I., Lisboa, A., Koblitz, R.V., Nunes da Cunha, C., Mendes Pontes, A.R., , 2013. Biodiversity and Integrated Environmental Monitoring (Biodiversidade e Monitoramento Ambiental Integrado). Áttema Editorial :: Assessoria e Design, Manaus.

Magnusson, W.E., Lima, A.P., Luizão, R., Luizão, F., Costa, F.R.C., Castilho, C.V.d., Kinupp, V.F., 2005. RAPELD: a modification of the Gentry method for biodiversity surveys in long-term ecological research sites. Biota Neotropica 5, 19-24.

Martins, A.C., Bernard, E., Gregorin, R., 2006. Inventários biológicos rápidos de morcegos (Mammalia, Chiroptera) em três unidades de conservação do Amapá, Brasil. Revista Brasileira de Zoologia 23, 1175-1184.

Michalski, L.J., Norris, D., de Oliveira, T.G., Michalski, F., 2015. Ecological Relationships of 645 Meso-Scale Distribution in 25 Neotropical Vertebrate Species. PLoS ONE 10, e0126114. http://dx.doi.org/10.1371/journal.pone.0126114. 
Muñiz-Miret, N., Vamos, R., Hiraoka, M., Montagnini, F., Mendelsohn, R.O., 1996. The economic value of managing the açaí palm (Euterpe oleracea Mart.) in the floodplains of the Amazon estuary, Pará, Brazil. Forest Ecology and Management 87, 163-173.

Normand, S., Vormisto, J., Svenning, J.-C., Grandez, C., Balslev, H., 2006. Geographical and environmental controls of palm beta diversity in paleo-riverine terrace forests in Amazonian Peru. Plant Ecology 186, 161-176.

Norris, D., Fortin, M.-J., Magnusson, W.E., 2014. Towards Monitoring Biodiversity in Amazonian Forests: How Regular Samples Capture Meso-Scale Altitudinal Variation in 25 km Plots. PLoS ONE 9, e106150. http://dx.doi.org/10.1371/journal.pone.0106150. Norris, D., Michalski, F., 2013. Socio-economic and spatial determinants of anthropogenic predation on Yellow-spotted River Turtle, Podocnemis unifilis (Testudines: Pelomedusidae), nests in the Brazilian Amazon: Implications for sustainable conservation and management. Zoologia (Curitiba) 30, 482-490. http://dx.doi.org/10.1590/S1984-46702013000500003 Oksanen, J., Blanchet, F.G., Kindt, R., Legendre, P., Minchin, P.R., Hara, R.B.O., Simpson, G.L., Solymos, P., Stevens, M.H.H., Wagner, H., 2015. vegan: Community Ecology Package. https://CRAN.R-project.org/package=vegan.

Oliveira, L.L., Cunha, A.C., Jesus, E.S., Barreto, N.J.C., 2010. Características Hidroclimáticas da 665 Bacia do Rio Araguari (AP). In: Cunha, A.C., Souza, E.B., Cunha, H.F.A. (Eds.), Tempo, Clima e Recursos Hídricos - Resultados do Projeto RMETAP no Estado do Amapá. IEPA, Macapá, pp. 83-96.

Pacheco, M.A.W., 2001. Effects of flooding and herbivores on variation in recruitment of palms between habitats. Journal of Ecology 89, 358-366. http://dx.doi.org/10.1046/j.1365-

$670 \quad 2745.2001 .00548 . x$.

Pebesma, E.J., Bivand, R., 2005. Classes and methods for spatial data in R. R News 5.

Pereira, L.A., Sena, K.S., dos Santos, M.R., Neto, S.V.C., 2008. Aspectos florísticos da FLONA do Amapá e sua importância na conservação da biodiversidade. Revista Brasileira de Biociências 5, pg. 693-695.

Peres, C.A., 1994. Composition, density, and fruiting phenology of arborescent palms in an Amazonian terra firme forest. Biotropica, 285-294.

Peres, C.A., 2000. Identifying keystone plant resources in tropical forests: the case of gums from Parkia pods. Journal of Tropical Ecology 16, 287-317.

Peres, C.A., 2011. Conservation in Sustainable-Use Tropical Forest Reserves. Conservation Biology 25, 1124-1129. http://dx.doi.org/10.1111/i.1523-1739.2011.01770.x. 
Poulsen, A.D., Tuomisto, H., Balslev, H., 2006. Edaphic and Floristic Variation within a 1-ha Plot of Lowland Amazonian Rain Forest. Biotropica 38, 468-478. http://dx.doi.org/10.1111/j.17447429.2006.00168.x.

Queiroz, J.A.L.d., Mochiutti, S., 2012. Guia prático de manejo de açaizais para produção de frutos. Embrapa Amapá, Macapá, Brazil.

R Core Team, 2015. R: A language and environment for statistical computing. 3.2.3. http://www.R-project.org/.

Reed, J., Van Vianen, J., Deakin, E.L., Barlow, J., Sunderland, T., 2016. Integrated landscape approaches to managing social and environmental issues in the tropics: learning from the past to guide the future. Global Change Biology. http://dx.doi.org/10.1111/gcb.13284.

Ribeiro Jr, P.J., Diggle, P.J., 2015. geoR: Analysis of Geostatistical Data. https://CRAN.Rproject.org/package=geoR.

Richards, M., 1993. The potential of non-timber forest products in sustainable natural forest management in Amazonia. The Commonwealth Forestry Review, 21-27. Rocha, A.d., Silva, M.d., 2005. Aspectos fitossociológicos, florísticos e etnobotânicos das palmeiras (Arecaceae) de floresta secundária no município de Bragança, PA, Brasil. Acta Botanica Brasilica 19, 657-667.

Salm, R., Prates, A., Simoes, N.R., Feder, L., 2015. Palm community transitions along a topographic gradient from floodplain to terra firme in the eastern Amazon. Acta Amazonica 45, 65-74.

Schneider, C., Coudel, E., Cammelli, F., Sablayrolles, P., 2015. Small-Scale Farmers' Needs to End Deforestation: Insights for REDD+ in São Felix do Xingu (Pará, Brazil). International Forestry Review 17, 124-142. http://dx.doi.org/10.1505/146554815814668963. Sezen, U.U., Chazdon, R.L., Holsinger, K.E., 2009. Proximity is not a proxy for parentage in an animal-dispersed Neotropical canopy palm. Proceedings of the Royal Society of London B: Biological Sciences, rspb. 2008.1793. http://dx.doi.org/10.1098/rspb.2008.1793. Sist, P., Ferreira, F.N., 2007. Sustainability of reduced-impact logging in the Eastern Amazon. Forest ecology and management 243, 199-209.

Smith, N., 2015. Palms and Cultural Landscapes. In, Palms and People in the Amazon. Springer, pp. 1-8.

Steele, M.Z., Shackleton, C.M., Shaanker, R.U., Ganeshaiah, K., Radloff, S., 2015. The influence of livelihood dependency, local ecological knowledge and market proximity on the ecological impacts of harvesting non-timber forest products. Forest Policy and Economics 50, 285-291. http://dx.doi.org/10.1016/i.forpol.2014.07.011. 
715 Svenning, J.-C., 2001. Environmental heterogeneity, recruitment limitation and the mesoscale distribution of palms in a tropical montane rain forest (Maquipucuna, Ecuador). Journal of Tropical Ecology 17, 97-113. http://dx.doi.org/do1:10.1017/S0266467401001067.

Svenning, J.C., 1999. Recruitment of tall arborescent palms in the Yasuni National Park, Amazonian Ecuador: are large treefall gaps important? Journal of Tropical Ecology 15, 355-366. http://dx.doi.org/10.1017/s0266467499000875.

Ter Steege, H., Pitman, N.C., Sabatier, D., Baraloto, C., Salomão, R.P., Guevara, J.E., Phillips, O.L., Castilho, C.V., Magnusson, W.E., Molino, J.-F., 2013. Hyperdominance in the Amazonian tree flora. Science 342, 1243092. http://dx.doi.org/10.1126/science.1243092. Ter Steege, H., Sabatier, D., Castellanos, H., Van Andel, T., Duivenvoorden, J., Adalardo de Oliveira, A., Ek, R., Lilwah, R., Maas, P., Mori, S., 2000. An analysis of the floristic composition and diversity of Amazonian forests including those of the Guiana Shield. Journal of tropical ecology $16,801-828$.

Terborgh, J., Andresen, E., 1998. The composition of Amazonian forests: patterns at local and regional scales. Journal of Tropical Ecology 14, 645-664.

730 Vedel-Sorensen, M., Tovaranonte, J., Bocher, P.K., Balslev, H., Barfod, A.S., 2013. Spatial distribution and environmental preferences of 10 economically important forest palms in western South America. Forest Ecology and Management 307, 284-292.

10.1016/j.foreco.2013.07.005.

Veloso, H.P., Rangel Filho, A.L.R., Lima, J.C.A., 1991. Classificação da vegetação brasileira, 735 adaptada a um sistema universal. Ministério da Economia, Fazenda e Planejamento, Fundação Instituto Brasileiro de Geografia e Estatística, Diretoria de Geociências, Departamento de Recursos Naturais e Estudos Ambientais.

Vormisto, J., Svenning, J.-C., Hall, P., Balslev, H., 2004. Diversity and dominance in palm (Arecaceae) communities in terra firme forests in the western Amazon basin. Journal of Ecology 92, 577-588. http://dx.doi.org/10.1111/j.0022-0477.2004.00904.x.

Weinstein, S., Moegenburg, S., 2004. Acai palm management in the Amazon Estuary: Course for conservation or passage to plantations? Conservation and Society 2, 315.

Wickham, H., 2009. ggplot2: elegant graphics for data analysis. Springer, New York. 